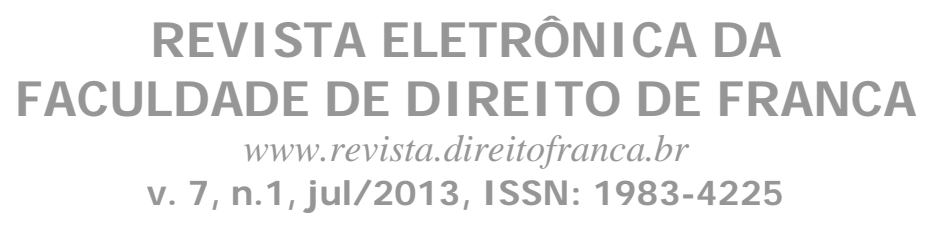

\title{
OBRIGAÇÕES VINCULATIVAS DOS ADQUIRENTES DE LOTES EM LOTEAMENTO FECHADO
}

Raquel Helena Valési

$\underline{\text { http://buscatextual.cnpq.br/buscatextual/visualizacv.do?id=K4458327H5 }}$

\begin{abstract}
Resumo: Este artigo analisará os loteamentos fechados que, apesar de não possuírem regulamentação específica, surgem no interesse de núcleos urbanos que desejam um sistema de fechamento de suas moradias e que os isole dos demais bairros ou loteamentos adjacentes.Com base nesse fechamento, surge internamente nesse núcleo urbano um condomínio de fato em que haverá a necessidade de ser implantada uma associação de moradores para que preste serviços necessários para manutenção e conservação desse loteamento (fechado), ou seja, torna-se necessária a contraprestação dos proprietários de lotes, assumindo o rateio das despesas comuns.
\end{abstract}

Palavras-chave: civil, loteamento, condomínio de fato, associação de moradores, taxa associativa

\section{Binding Obligations of Lots' Purchasers in Closed Allotments}

Abstract: This article will analyze the closed allotments that, although not having specific regulations, arise in the interest of urban nuclei that desire a closed system of its housing and that isolate other neighborhoods or adjacent allotments. Based on this allotments, a de facto condominium arises internally in this urban nucleus. Hence there will be the necessity of the implementation of a residents' associations to provide necessary services for the maintenance and conservation of such closed allotment; in other words, the owners of those lots will be subject to payment assuming the apportionment of common expenses.

Keywords: civil, allotments, de facto condominium, residents' association, association tax.

\section{I - INTRODUÇÃO}

Da necessidade de uma melhor qualidade de vida, as pessoas acabam criando novas formas de melhor usufruir do solo.

Uma dessas formas é encontrada nos chamados loteamentos fechados, um fato social originado pela insegurança que atinge as cidades e que não possuem legislação específica muito embora são inspirados nos princípios da propriedade horizontal.

No loteamento fechado, o condomínio de fato que surge dentro dele decorre das regras de convivência em comum criadas pelos proprietários de lotes nesse tipo de 


\section{REVI STA ELETRÔNI CA DA FACULDADE DE DIREITO DE FRANCA \\ www.revista.direitofranca.br \\ v. 7, n.1, jul/ 2013, I SSN: 1983-4225}

empreendimento imobiliário, e é um exemplo do conflito que se estabelece entre o fato e o Direito. Como os serviços públicos não são prestados pelo Poder Público, a sociedade cria mecanismos para absorver essa omissão a fim de obter bem-estar, mas que muitas vezes é incompatível com o ordenamento legal já existente, ou seja, não há norma específica para a espécie em questão e por vezes as existentes não se adaptam à situação de fato.

Assim, na tentativa de solucionar tal questão, buscar-se-á definir o que seja o loteamento fechado, bem como se forma o vínculo jurídico entre associação e proprietários de lotes. Buscar-se-ão os mecanismos legais que correspondam e supram as necessidades desse grupo social, levando em consideração que, apesar de juridicamente o loteamento fechado ou a associação constituída entre os proprietários de lotes não se confundir com a figura do condomínio da Lei 4.591/64, no plano fático essas figuras se assemelham pois ambas exigem os serviços comunitários que beneficiam todos os componentes dessa coletividade, proporcionando melhores condições de conforto e segurança, valorizando seus imóveis e, portanto, a não participação do rateio das despesas comuns implicaria em verdadeiro enriquecimento sem causa, o que é vedado pelo ordenamento jurídico brasileiro.

Nessas condições, será iniciado o trabalho com uma apresentação da propriedade em si mesma e sua função social, e de que forma hoje ela se realiza à luz do Código Civil e da Constituição Federal de 1988.

Após, apresentaremos a propriedade em algumas de suas facetas, ou seja, de que forma ela se expressará no condomínio tradicional, no condomínio edilício e no parcelamento do solo urbano.

E por fim, o loteamento fechado, a posição jurisprudencial e doutrinária acerca dessa "nova modalidade”, encerrando com o apontamento das obrigações que podem vincular o adquirente de lotes ao pagamento do rateio mensal.

\section{A FUNÇÃO SOCIAL E O DIREITO À PROPRIEDADE NO CÓDIGO CIVIL BRASILEIRO}




\section{REVI STA ELETRÔNI CA DA FACULDADE DE DIREITO DE FRANCA \\ www.revista.direitofranca.br \\ v. 7, n.1, jul/ 2013, I SSN: 1983-4225}

Gustavo Tepedino ${ }^{1}$ leciona que a propriedade tem sido estudada sob dois aspectos: o estrutural e o funcional. A doutrina, tradicionalmente, acaba por dar maior relevância ao primeiro aspecto até o presente momento, mas paulatinamente está se pronunciando sobre o segundo aspecto do direito de propriedade nas publicações mais recentes e, será analisado a seguir.

O Código Civil Brasileiro de 2002, da mesma forma que o de 1916, não define o direito de propriedade em seu artigo 1.228, acaba apenas dispondo acerca de seu conteúdo, relacionando os poderes conferidos ao proprietário como o uso, fruição e disposição da coisa e de reavê-la do poder de quem injustamente a possua ou detenha. Esses poderes fazem parte da estrutura do direito de propriedade.

De toda forma, pela atuação direta dos princípios que norteiam o Código Civil/2002 (§ $1^{\circ}$, do art. 1.228), fica claro que aquela característica da propriedade vista como absolutista recebe tratamento diferenciado do que era previsto na codificação revogada. O absolutismo individual, que representava o arbítrio do proprietário de fazer do bem tudo aquilo que desejava e que já vinha recebendo chancelas, acaba por curvarse ante a visão da utilização da propriedade sempre em consonância com a finalidade social.

A idéia social da propriedade noticiada pelo Código Civil/2002 encontra-se diferenciada de pretensões do passado, em que se afirmava que a função social da propriedade, necessariamente, implicaria na "proletarização" do Direito Civil. ${ }^{2} \mathrm{O}$ legislador ao afirmar que o direito de propriedade deve ser exercido com "as suas

\footnotetext{
1 TEPEDINO,Gustavo. Contornos constitucionais da propriedade privada in Temas de Direito Civil, 2 ed.Rio de Janeiro:Renovar, 1999, p. 269-314.

'SAVATIER, Rene: “Recordando que alguns falam em socialização, outros em 'publicização' do Direito Civil, entende que melhor se dirá ‘proletarização’ desse Direito, pelo declínio das instituições que se inspiravam nas concepções e nos modos de vida 'burgueses', surgindo um Direito novo, assinalado pelo modo de vida e pelas concepções 'proletárias'; e salienta a preocupação principal do Código, com os imóveis, porque representam uma fortuna particularmente sólida e durável, e que a concepção burguesa da fortuna privada não aspirava somente torná-la estável, mas considerava como normal aumentá-la progressiva e indefinidamente, por economia. A valorização do trabalho - diz - em relação ao capital puro corresponde a uma idéia de Justiça. E, fazendo considerações sobre as empresas e os ofícios, o capital e o trabalho, diz - que a evolução atual do Direito Civil tende a 'minimizar' a velha fortuna adquirida, cujo estatuto era a grande preocupação do Direito tradicional; - que o conjunto das instituições é atravessado por uma corrente que, valorizando o trabalho atual, cria no Direito um clima novo. O grande civilista se manifesta, pois, contra a propriedade individual, como se ela fosse a causa das desigualdades sociais, esquecendo-se dos lucros enormes que auferem as indústrias, e de que a solução está na participação dos operários nos lucros das empresas. O capital, imobiliário, juntamente com o trabalho operário, produzem os lucros, uma parte dos quais deve ser atribuída ao operário” (in Código Civil Comparado, São Paulo:Revista dos Tribunais, 1962, p. 335).
} 


\section{REVI STA ELETRÔNI CA DA FACULDADE DE DIREITO DE FRANCA \\ www.revista.direitofranca.br \\ v. 7, n.1, jul/ 2013, I SSN: 1983-4225}

finalidades econômicas e sociais” não assinalou que pretende implementar uma “política do proletariado”, mas, em rumo diverso, buscou eliminar o arbítrio abusivo do proprietário sobre o bem quando este puder ser utilizado por terceiro(s) que demonstrem objetiva intenção de atar a propriedade na vida social ou econômica com a sua utilização viável. $^{3}$

Conclui-se, assim, não ter cabimento a idéia de que a função social da propriedade afastou a autonomia privada no direito de propriedade, ${ }^{4}$ não resta dúvida de que o novo Código Civil não aboliu a propriedade como direito absoluto, exclusivo e perpétuo. Contudo, também não há dúvida de que o exercício dos poderes inerentes à propriedade deve obediência a uma das mais importantes cláusulas gerais da nova codificação que é a função social da propriedade, tudo em consonância com os incisos XXII e XXIII do art. 5º da Constituição Federal de 1988.

Estamos hoje diante de um direito de propriedade garantido e assegurado pela Constituição Federal contra abusos do próprio proprietário e do Poder Público, todavia esse mesmo direito está absolutamente comprometido com a realização da função social do bem imóvel e ainda participando de uma relação complexa (intrínseca e extrínseca)

Sendo assim, a propriedade se justifica socialmente diante de sua funcionalidade, que lhe dá contornos de respeito aos interesses coletivos, e assegura a dignidade da pessoa humana, princípio constitucional que é norteador de toda legislação inferior à Constituição Federal.

\footnotetext{
${ }^{3}$ Ademais, como bem assinala Luis Edson Fachin, sobre a função social da propriedade, na vertente da utilização do bem, "não chega a afirmar que o trabalho se constitui no único modo para ter a propriedade: afirma que somente o trabalho do homem sobre a terra é que legitima a sua propriedade. Como se vê, são duas posições excludentes, contudo, basicamente, distintas. A primeira consiste numa inversão entre domínio e trabalho; a segunda tão somente inclui no bojo do domínio o elemento trabalho, como fator de legitimação, mas não como condição sine qua non para adquirir o direito de propriedade" in A função social da posse e a propriedade contemporânea (uma perspectiva de usucapião imobiliária rural), Sergio Antonio Fabris Editor: Porto Alegre, 1988, p. 18).

${ }^{4}$ Como bem conclui Francisco Eduardo Loureiro: “A autonomia privada não desapareceu e nem tende a desaparecer no direito de propriedade. Apenas os limites e restrições à autonomia e liberdade contratual, que já se encontravam assimilados em nosso conhecimento, devem ser estendidos à propriedade. $\mathrm{O}$ direito de propriedade deve afeiçoar-se ao novo modelo, que impõe respeito e equilíbrio aos interesses nãoproprietários, em busca da igualdade substancial" (inA Propriedadecomo relação jurídica complexa. Rio de Janeiro: Renovar, 2003, p. 189)
} 


\section{REVI STA ELETRÔNI CA DA FACULDADE DE DIREITO DE FRANCA \\ www.revista.direitofranca.br \\ v. 7, n.1, jul/ 2013, I SSN: 1983-4225}

\section{O CONDOMÍNIO EDILÍCIO E O PARCELAMENTO DO SOLO URBANO BRASILEIRO}

\subsection{DO CONDOMÍNIO EDILÍCIO}

O condomínio edilício ou propriedade horizontal surge através de uma atividade humana que promove e realiza a construção de prédios ou casas assobradadas, chamada incorporação imobiliária.

Para haver a incidência da Lei 4.591/64, é necessário que a aquisição de fração ideal do terreno esteja atrelada à obrigação de construir, ou seja, a Lei 4.591/64 foi editada com o fim específico de regulamentar as edificações em condomínio, ou seja, a construção em forma de unidades autônomas.

O condomínio previsto neste artigo $8^{\circ}$ da Lei 4.591/64 é uma modalidade especial de aproveitamento condominial do espaço de uma gleba, onde não existem ruas, praças ou áreas livres públicas. Às unidades autônomas que se constituírem de casas térreas ou assobradadas, será discriminada a parte do terreno ocupada pela edificação e também aquela fração ideal sobre a totalidade do terreno e partes comuns. ${ }^{5}$

As unidades autônomas apenas receberão identificação registrária própria após a conclusão da construção, quando se verificar sua averbação no registro de imóveis e o empreendimento for submetido à instituição, especificação e convenção condominial ${ }^{6}$, somente então é que cada unidade autônoma passa a ser distinguida com tributação municipal específica e não poderá ser alterada sua destinação por iniciativa isolada de seus titulares. ${ }^{7}$

Assim sendo, vamos verificar como se dará o parcelamento do solo urbano brasileiro, de que modo ele se diferencia da figura do condomínio edilício, como foi sua evolução, os desdobramentos face o desenvolvimento incontido das cidades, e, principalmente, atentaremos quanto a missão social do urbanismo na ordenação dos

\footnotetext{
${ }^{5}$ FREITAS, José Carlos de. Da Legalidade dos Loteamentos Fechados, Revista dos Tribunais $\mathrm{n}^{\circ} 750$, Abril/1998, p. 152-153.

${ }^{6}$ Nos edifícios e casas cada unidade autônoma terá sua identificação numérica, correspondendo-lhe uma fração ideal no terreno em que foi constituída e nas coisas comuns, expressa de forma decimal ou ordinária.

${ }^{7}$ KOJRANSKI, Nelson. Loteamento e condomínio fechados, Jornal Tribuna do Direito, Janeiro/1999, p.10.
} 


\section{REVI STA ELETRÔNI CA DA FACULDADE DE DIREITO DE FRANCA \\ www.revista.direitofranca.br \\ v. 7, n.1, jul/ 2013, I SSN: 1983-4225}

espaços habitáveis para assegurar à população melhores condições de vida no aglomerado humano.

\subsection{DO PARCELAMENTO DO SOLO URBANO}

É considerado o parcelamento do solo urbano como o processo de urbanificação de uma gleba, ou seja, é uma atividade que consiste no fracionamento de uma gleba em unidades menores destinadas à edificação futura. O parcelamento do solo urbano importará na alteração por completo das características da gleba com o fim de integrá-la à urbe, agregá-la ao espaço urbano, o que será feito através da oferta de imóveis destinadas à moradia da população ${ }^{8}$.

O parcelamento do solo urbano, portanto, pode ser caracterizado pelas várias formas de regular juridicamente o solo urbano, e as linhas mestras que traçam as normas que regulam o parcelamento do solo urbano será vista na Lei 6.766/79, com algumas alterações da Lei 9.785/99. Nesse diploma legal (Lei 6.766/79), serão especificadas as duas espécies de parcelamento do solo que são o desmembramento e o loteamento, ambos tratam da divisão de uma gleba em lotes destinados à edificação.

Para que surja o loteamento, é necessário que se siga um procedimento adequado, ou seja, voluntário e formal do proprietário da gleba que planeja sua divisão, e que necessariamente a submeterá à aprovação da Prefeitura para subseqüente inscrição no Registro de Imóveis. Também haverá necessidade de transferência gratuita das áreas das vias públicas e espaços livres ao Município, ficando ao final de todo o processo de aprovação, responsável pela coleta de lixo, segurança, conservação das vias públicas, dentre outros dentro dos loteamentos.

Com a aprovação do projeto de loteamento, também verificaremos que a identidade da gleba original desaparece, surgindo os lotes com individualidade própria, ou seja, identidade imobiliária, localização física determinada pela fragmentação da gleba original, medidas próprias e confrontações que os localizam materialmente na gleba primitiva.

Dessa forma, diferentemente do Condomínio (Lei 4.591/64 e 1.331 a 1.358, do Código Civil) em que a edificação representa uma obrigação indissociável, no

\footnotetext{
${ }^{8}$ AZEVEDO, Marcelo Sampaio Soares de. “O loteamento fechado na legislação municipal”. Dissertação de Mestrado, PUC/SP, 2002, pag. 37
} 


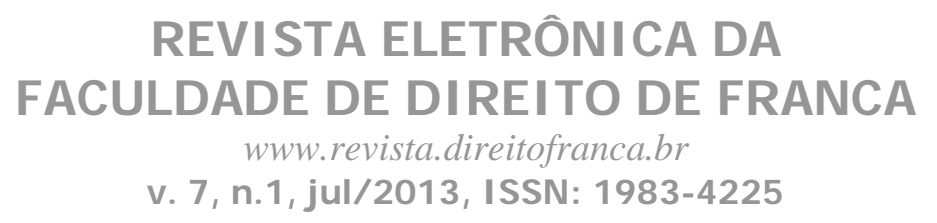

loteamento, essa vinculação de construir não existe na aquisição do lote e nem o loteador impõe o tipo de edificação a ser levantada. Pode o adquirente construir como e quando quiser, mas desde que obedecidas as restrições urbanísticas impostas no projeto de loteamento e satisfeitas as posturas municipais.

\section{DO LOTEAMENTO FECHADO E $O$ POSICIONAMENTO JURISPRUDENCIAL E DOUTRINÁRIO}

Com o crescimento desordenado das cidades, pelo próprio processo de urbanização, constataremos que será afetado o sistema de transportes, proliferação de habitações sem a regular ocupação do solo, precariedade do saneamento básico, aumento da violência, dentre outras situações desastrosas típicas de um crescimento desenfreado e sem planejamento urbano.

Pelas situações acima elencadas, ou seja, pela má qualidade de vida urbana gerada por essa ocupação inadequada do solo nos grandes centros urbanos e interior, alguns empreendedores do ramo imobiliário têm implantado empreendimentos dotados de comodidade, segurança, saneamento básico, dentre outros atrativos que não são oferecidos nos centros urbanos pelo Poder Público. ${ }^{9}$

Dessa forma, surge uma nova modalidade ${ }^{10}$ de parcelamento de solo urbano chamado loteamento fechado ${ }^{11}$, com características especiais que acabam se diferenciando dos loteamentos convencionais, apesar de seguirem os mesmos requisitos urbanísticos exigidos para implantação de um loteamento.

Diferentemente dos loteamentos convencionais, esses loteamentos fechados carecem de legislação específica, e a falta de previsão legal cria alguns impasses aos

\footnotetext{
${ }^{9}$ FREITAS, José Carlos de. Da Legalidade, op.cit., p. 149. No mesmo sentido, ERPEN, Décio Antonio; PAIVA, João Pedro Lamana; MEZZARI, Mario Pazutti. Condomínio Horizontal de Lotes, op.cit., p 70. KOJRANSKI, Nelson. Loteamento e Condomínio Fechados, Jornal Tribuna do Direito, op.cit.,p. 10.

${ }^{10}$ Para alguns autores trata-se de nova modalidade de parcelamento do solo urbano pois já prevista na Lei 6.766/79, para outros trata-se de uma nova espécie de parcelamento e que, por não haver previsão na legislação federal, implica na incompetência legislativa do Município em legislar sobre esse assunto, pois essa matéria é de competência exclusiva da União.

${ }^{11}$ A doutrina e jurisprudência têm usado muito os seguintes termos para designar o mesmo empreendimento do tipo loteamento fechado, tais como: loteamento reservado, condomínio fechado, loteamentos integrados, loteamentos em condomínio, loteamentos especiais, condomínios horizontais ou especiais . In, FREITAS, José Carlos de. Da Legalidade,op.cit., p. 149; RIZZARDO, Arnaldo. Promessa de compra, op.cit., p. 49; MEIRELLES, Hely Lopes. Direito Municipal, op.cit., p. 541;GASPARINI, Diógenes. Loteamento em Condomínio, Revista de Direito Público, n 68, p. 319.
} 


\section{REVI STA ELETRÔNI CA DA FACULDADE DE DIREITO DE FRANCA \\ www.revista.direitofranca.br \\ v. 7, n.1, jul/ 2013, I SSN: 1983-4225}

empreendedores e adquirentes tendo em vista que os mesmos pretendem segurança jurídica à sua propriedade imobiliária ${ }^{12}$, bem como estabelecer regras de convivência que estejam em compasso com os propósitos dos moradores e empreendedor imobiliário.

O loteamento fechado tem como particularidade o fato de o proprietário do lote gozar do direito de propriedade como qualquer titular sobre o imóvel integrante de parcelamento tradicional, devendo contudo observar algumas condições para que haja existência de fato desse tipo de loteamento, tais como: a) que o loteamento deve estar cercado ou murado em seu perímetro; b) o acesso deve ser feito por um ou dois locais, com portaria e guarita nessas entradas, submetendo o morador à identificação prévia; c) as ruas, as praças, as vias de comunicação e outros logradouros públicos ou espaços livres têm seu acesso limitado aos proprietários dos lotes e às pessoas que eles autorizam entrar, o que é feito através de permissão ou concessão de uso de bem público, outorgado pelo Município; d) as vias de comunicação, praças e espaços livres do loteamento são de propriedade do Município, alterando-se apenas o direito de uso concedido somente aos proprietários de lote daquele loteamento; e) haverá necessidade de manutenção e conservação das vias de circulação, praças e espaços livres quando o Município não se incumbe de fazer; f) a manutenção da portaria, serviço de vigilância, coleta de lixo, captação, tratamento e distribuição de água e esgoto, pavimentação, limpeza das ruas, dentre outros serviços, são prestados por uma associação de moradores que administrará o funcionamento do loteamento, gestão da receita, da despesa e da cobrança pelos serviços prestados. ${ }^{13}$

Nasce assim o condomínio de fato, que, repita-se, adveio de um mecanismo voltado a preencher a omissão pública nos loteamentos fechados, sem se preocupar com os moldes impostos pelo legislador. ${ }^{14} \mathrm{O}$ fato de o condomínio atípico ou de fato não encontrar previsão normativa não significa que não exista no mundo real, fato é que a jurisprudência e doutrina vêm construindo fonte paralela para suprir tal lacuna. ${ }^{15}$

\footnotetext{
12 KOJRANSKI, Nelson. Loteamento Fechado, Revista do Instituto dos Advogados de São Paulo, op.cit., p 129. Nesse sentido MEIRELLES, Hely Lopes. Direito Municipal Brasileiro,op.cit., p 541.

${ }^{13}$ SOARES, Danielle Machado. Condomínio de Fato, editora Renovar, p. 68-70.

14 SOARES, Danielle Machado. Condomínio,op.cit., p. 82.

${ }^{15}$ COBRANÇA - Taxa de Manutenção - Associação de Moradores - Taxa destinada à manutenção e melhorias em "loteamento fechado" - Admissibilidade - Serviços queservem a todos os proprietários,
} 


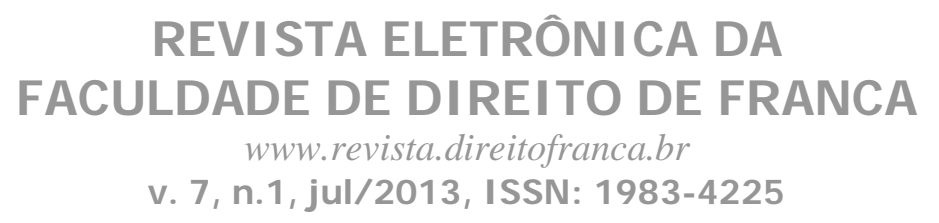

Agravo no recurso especial - Loteamento aberto ou fechado - Condomínio atípico - Sociedade prestadora de serviços - Despesas - Obrigatoriedade de pagamento. O proprietário de lote integrante de loteamento aberto ou fechado, sem condomínio formalmente instituído, cujos moradores constituíram sociedade para prestação de serviços de conservação, limpeza e manutenção, deve contribuir com o valor correspondente ao rateio das despesas, pois não se afigura justo nem jurídico que se beneficie dos serviços prestados e das benfeitorias realizadas sem a devida contraprestação. Precedentes. (STJ - $3^{\mathrm{a}}$ Turma; Ag.Reg. no Resp $n^{0}$ 490.419-SP, rel. Min. Nancy Andrighi; j. 10/06/03; v.u.)

Dessa forma, o loteamento fechado possui natureza jurídica híbrida e dúplice concomitantemente. É híbrida porque possui ao mesmo tempo características do direito obrigacional e do direito real. Ao sofrer influência do princípio da autonomia privada os proprietários de lotes constituem uma associação com o objetivo de atuar de forma condominial no que se refere aos seus interesses privados com incidência sobre um bem público, especificamente, de uso comum do povo. Anatureza dúplice atribuída ao loteamento fechado se dá devido à fusão de dois institutos tradicionais, o loteamento e o condomínio horizontal, que dão origem a essa nova modalidade. Também adquire esse caráter dúplice em razão da titularidade do proprietário do lote que é plena nos moldes tradicionais, e assemelha-se com a unidade autônoma do condomínio horizontal. ${ }^{16}$

É por essa razão que podemos dizer também que os loteamentos fechados são inspirados nos princípios da propriedade horizontal por se assemelharem, ou seja, o domínio exclusivo de cada lote pertence a cada um dos seus proprietários, e o domínio comum, o uso das partes comuns, é exercido pelos proprietários dos lotes sobre o logradouro público mediante permissão ou concessão de uso, sendo que a sua manutenção e conservação são realizadas pela administração eleita pelos proprietários dos lotes, mediante rateio das despesas. ${ }^{17}$

\section{DAS OBRIGAÇÕES QUE VINCULAM OS ADQUIRENTES DE LOTES EM LOTEAMENTO FECHADO}

\section{1 - CONSIDERAÇÕES INICIAIS}

sendo admissível a sua cobrança, independentemente de adesão ou não à Associação - Recurso não provido. (Apelação Cível nº 94.566-4 - Mairiporã - 10a Câmara de Direito Privado - TJSP - Rel. Ruy Camilo - 11/04/00 - v.u.).

${ }^{16}$ SOARES, Danielle Machado. Condomínio, op.cit., p. 83.

${ }^{17}$ SOARES, Danielle Machado. Condomínio,op.cit., p. 85. 


\section{REVI STA ELETRÔNI CA DA FACULDADE DE DIREITO DE FRANCA \\ www.revista.direitofranca.br \\ v. 7, n.1, jul/ 2013, I SSN: 1983-4225}

Nosso trabalho até aqui tentou demonstrar como a propriedade pode manifestarse no condomínio edilício e no parcelamento do solo urbano através de suas duas espécies, a do loteamento e do desmembramento, e, por último, um novo modelo de propriedade advinda da transformação e necessidade social, ou seja, uma nova modalidade de loteamento com características próprias e adotadas por uma coletividade cujo modo de viver e valorar as formas de socialidade em grupo se adapta, o chamado loteamento fechado.

Diante dessa nova modalidade de loteamento, haverá necessidade, para existência desse complexo, de serviços essenciais para seu funcionamento e utilização, sendo que o custeio das obras e serviços empregados deverão ser rateados entre os titulares dos lotes (ditos condôminos ou associados). ${ }^{18}$ Mesmo que a rigor, a obrigação da manutenção, segurança e limpeza nesses loteamentos devesse ser da municipalidade, nada impede que os agrupamentos sociais (Associação de Moradores) estabeleçam suas próprias regras com a criação de encargos próprios para melhorar e conservar o padrão do empreendimento.

Nesses loteamentos fechados acaba-se criando um complexo de direitos, obrigações e deveres próprios, e, dessa forma, deve-se encontrar uma maneira para ratear as despesas com a manutenção das vias internas, ruas, praças, rede elétrica, distribuição de água, coleta de lixo, vigilância, dentre outros. Em suma, é necessário estabelecer os direitos e obrigações, a forma de administração, aproximando-se de forma análoga à do condomínio em edifícios. ${ }^{19}$

\subsection{DA ACEITAÇÃO TÁCITA AOS SERVIÇOS PRESTADOS PELA ASSOCIAÇÃO DE MORADORES}

Muito embora a grande maioria dos loteamentos ao elaborarem seus contratospadrões introduzam além das restrições de uso e ocupação também as obrigações dos compradores de participarem do rateio mensal para manutenção e conservação do empreendimento, em alguns casos não há essa menção expressa.

\footnotetext{
${ }^{18}$ ARAGÃO, Severiano Ignácio de. Regime Jurídico do Condomínio Fechado, Rio de Janeiro: Forense, 2001,p.03.

${ }^{19}$ VIANA, Marco Aurélio. Loteamento Fechado e Loteamento Horizontal, Rio de Janeiro:Aide., p 29.
} 


\section{REVI STA ELETRÔNI CA DA FACULDADE DE DIREITO DE FRANCA \\ www.revista.direitofranca.br \\ v. 7, n.1, jul/ 2013, I SSN: 1983-4225}

Assim, cria-se margem de questionamento por muitos adquirentes de lotes se devem ou não contribuir com o rateio mensal, se estariam ou não associados àquela associação de moradores criada para gerir os recursos e fornecer os serviços para manutenção e conservação do loteamento.

Nesses loteamentos fechados, nos quais as pessoas (proprietários de lotes) se organizam formando um condomínio de fato ou atípico e apresentam despesas que devem ser custeadas por toda coletividade que se beneficia dos serviços prestados, todavia, têm-se enfrentado oposição a este rateio com base no inciso XX do artigo $5^{\circ}$ da Constituição Federal que prescreve que "ninguém poderá ser compelido a associar-se ou permanecer associado”.

Em que pese essa posição, vejamos. A liberdade plena de associação que é atribuída ao indivíduo em sede constitucional constitui uma espécie de cláusula geral da tutela da pessoa humana, o que implica em dizer que está na garantia do livre desenvolvimento de sua personalidade. A Associação é merecedora de tutela enquanto for idônea para consentir a formação e o desenvolvimento dos seus associados que, quando alcançam o escopo associativo, realizam a si mesmos. ${ }^{20}$ A formação social tem valor constitucional somente se atender à função do livre desenvolvimento da pessoa. ${ }^{21}$

Se confrontarmos o princípio constitucional da liberdade de associação que cada indivíduo possui, pois, inerente à sua personalidade, com a cláusula geral (arts. 884 a 886 do Código Civil) que nega o enriquecimento sem causa, a manifestação majoritária tanto da doutrina quanto da jurisprudência é a da predominância da condenação do enriquecimento sem causa, ainda que se levantem dúvidas acerca dos benefícios oriundos da Associação. O proprietário de lote em loteamento fechado faz parte de uma comunidade que aderiu à hipótese associativa, e que, ainda que de forma indireta, obtém vantagens dos serviços prestados pela Associação além da valorização imobiliária. ${ }^{22}$

O comportamento concludente das partes faz demonstrar que a vontade, ou seja, o consentimento seja comunicado mediante uma declaração que não necessariamente

\footnotetext{
${ }^{20}$ PERLINGIERI, Pietro. "Perfis do Direito Civil”.2ed. Editora Renovar, 2002, p. 300-301.

${ }^{21}$ PERLINGIERI, Pietro. Perfis, op.cit., p. 30.

${ }^{22}$ ARAGÃO, Severiano Ignacio de. Regime Jurídico,op.cit. ,p. 06 ensina que: "partindo-se da presunção de adesão implícita ao estatuto associativo, pois, carente o loteamento fechado de serviços suplementares de infra-estrutura e regular funcionamento, a ninguém é lícito adquirir unidade favorecida necessariamente pelos benefícios proporcionados, sem os ônus dessa fruição, pena de endeusar o enriquecimento ilícito".
} 


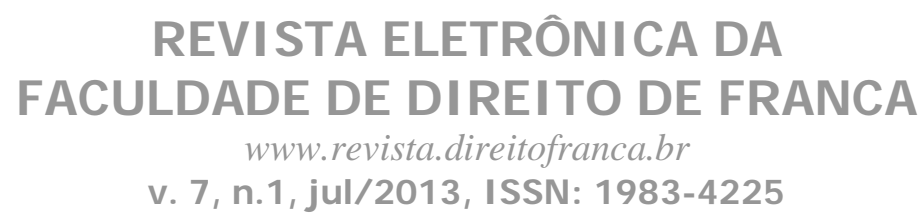

tenha sido feita da forma expressa, mas resulta de outros comportamentos do sujeito, de uma manifestação tácita de vontade. Essa manifestação tácita não implica em dizer que tenha sido o silêncio sua declaração de vontade ${ }^{23}$ mas, sim, as suas ações, determinados comportamentos (como no caso de receber e aceitar os serviços prestados pela associação), que fará manifestar sua vontade. De um comportamento deste tipo, silencioso, mas de molde a denunciar de forma inequívoca, no quadro das circunstâncias existentes, a vontade de concluir o contrato, diz-se comportamento concludente. ${ }^{24}$

Dessa forma, a vontade de aceitar, de aderir, não é expressa, mas resulta implicitamente, de forma operativa, da atitude e da atividade do sujeito. ${ }^{25}$ Tomando a matéria analisada pela oferta e prestação de serviços, verificamos que há aceitação tácita do adquirente de lote em loteamento fechado que se utiliza desses serviços, criando-se uma relação contratual de fato. ${ }^{26} \mathrm{O}$ gozo dos serviços pelo proprietário importa na aceitação tácita da oferta. ${ }^{27}$

A aceitação dos serviços prestados pela Associação gera um efeito negocial, que fixa o sujeito vinculado por seu comportamento, pela conduta que assume perante determinada circunstância fática.

\subsection{DO ENRIQUECIMENTO SEM CAUSA}

\footnotetext{
${ }^{23}$ Artigo 111 do CC: $O$ silêncio importa anuência, quando as circunstâncias ou os usos o autorizem, $e$ não for necessária a declaração de vontade expressa.

Artigo 112 do CC:Nas declarações de vontade se atenderá mais à intenção nelas consubstanciadas do que o sentido literal da linguagem.

${ }^{24}$ ROPPO, Enzo. O Contrato ,Coimbra:Almedina, 1998, pag. 94

${ }^{25}$ ROPPO, Enzo. O Contrato, op.cit., p 94.

${ }^{26}$ COSTA, Mario Julio de Almeida inDireito das Obrigações, Coimbra:Almedina, 1999,p. 192-193 que a doutrina e jurisprudência alemãs ponderam acerca de uma nova figura jurídica, a chamada relações contratuais de fato. Alguns autores entendem mais adequado o qualificativo de comportamentos sociais típicos (sozialtypische Verhalten), porque ele não induz à conclusão erronea de que se trata de processos extrajurídicos e, ao mesmo tempo, salienta o aspecto, adiante considerado, de que a atribuição de relevância jurídica a tais situações resulta de uma valoração objectiva e não propriamente da vontade negocial dos participantes.

LOTEAMENTO - Ação de cobrança de taxa de manutenção - Improcedência - Administração exercida por associação civil - equiparação a condomínio fechado - obrigatoriedade do pagamento, diante dos serviços que são postos à disposição dos proprietários - ausência de ofensa ao artigo $5^{\circ}$, inciso $\mathrm{XX}$ da $\mathrm{CF}$ - recurso provido. (Apelação cível 144.973-4 - São Paulo - $3^{\text {a }}$ Câmara de Direito Privado - rel. Carlos Roberto Gonçalves - j.14/03/00, v.u.)

${ }^{27}$ CASTRO, Flávia de Almeida Viveiros. Obrigações propter reme condomínio atípicos. RT, no 799/64, maio/2000, p. 72.
} 


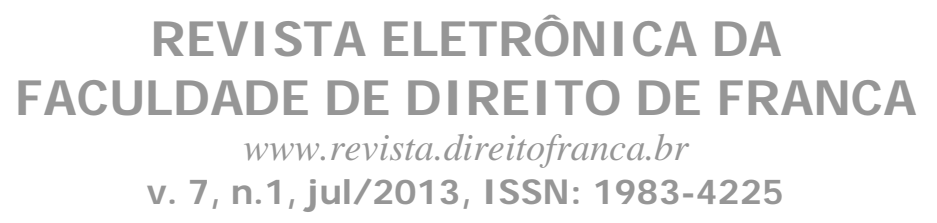

Se ainda não fosse possível sustentar a tese da cobrança do rateio pela aceitação tácita, há como dar suporte à cobrança pela vedação do enriquecimento sem causa. Assim vejamos.

As relações jurídicas obrigacionais exigem uma conduta ética compatível com a dignidade da pessoa humana, voltada ao social, de mútuo respeito entre os sujeitos do negócio jurídico, por conseqüência a Constituição Federal não permite que as relações jurídicas obrigacionais sejam indignas, se tutela a livre iniciativa e assegura a autonomia privada, não poderia permitir a subsistência de relações jurídicas que importassem num enriquecimento sem causa. ${ }^{28}$

O enriquecimento sem causa é visto como uma melhoria da situação patrimonial da pessoa que deve corresponder a uma perda avaliável em dinheiro sofrido por uma outra pessoa. Nessas condições, nos deparamos com essa situação nos loteamentos fechados, quando alguns moradores recusam-se a participar do rateio das despesas comuns, deixando que o resto daquele grupo social empobreça, pois arca com a parcela devida pelo proprietário que não participa do rateio. Conseqüentemente, haverá enriquecimento sem causa por parte destes moradores que não participam do rateio, pois gozam dos mesmos serviços destinados a todos indistintamente sem pagar por eles, além de seu próprio bem imóvel ser valorizado pela simples oferta desses mesmos serviços. $^{29}$

Para Severiano Aragão ${ }^{30}$, "basta que os serviços e utilidades sejam postos à disposição do condômino ou titular da unidade para ficar sujeito à cota de rateio das despesas e sendo indiferente o consumo ou o desfrute individual de cada condômino. As despesas nos loteamentos fechados devem atender às peculiaridades próprias dos mesmos, tais e tantas forem as diversidades de situações”.

\subsection{ASPECTOS DE UMA NOVA VISÃO DO DIREITO OBRIGACIONAL COM INCIDÊNCIA DAS NORMAS CONSTITUCIONAIS NO DIREITO CIVIL}

O ordenamento se compõe de diversas normas que têm sua origem nos poderes distintos, seja pelo Congresso, sindicatos, particulares, mas sempre estabelecendo entre

\footnotetext{
${ }^{28}$ NANNI, Giovanni Ettore. Enriquecimento, São Paulo:Saraiva, 2004, p. 94-95.

${ }^{29}$ CASTRO, Flavia de Almeida Viveiros. Obrigações,op.cit., p. 73.

${ }^{30}$ ARAGÃO, Severiano Ignacio de. Regime Jurídico,op.cit., p. 36.
} 


\section{REVI STA ELETRÔNI CA DA FACULDADE DE DIREITO DE FRANCA \\ www.revista.direitofranca.br \\ v. 7, n.1, jul/ 2013, I SSN: 1983-4225}

essas normas uma hierarquia rígida representada por uma pirâmide, ou seja, todas as normas devem estar em harmonia com a Constituição Federal.

O respeito à Constituição implica não somente a observância de certos procedimentos para emanar a norma (infraconstitucional), mas, também, a necessidade de que o seu conteúdo atenda aos valores presentes na própria Constituição. As normas ordinárias devem se inspirar nas normas constitucionais pois elas ditam os princípios de relevância geral. Os princípios são normas, daí a razão das normas constitucionais poderem ser aplicadas isoladamente (quando não existirem normas ordinárias que disciplinem o fato jurídico em consideração) como fonte da disciplina de uma relação jurídica de direito civil. $^{31}$

Os princípios são normas, daí a razão das normas constitucionais poderem ser aplicadas isoladamente (quando não existirem normas ordinárias que disciplinem o fato jurídico em consideração) como fonte da disciplina de uma relação jurídica de direito civil. $^{32}$

Podemos ainda afirmar que, seja na aplicação dita indireta (quando há lei ordinária específica, ou cláusula geral, ou princípios expressos), seja na aplicação direta (entendendo esta quando há ausência de norma ordinária específica), a norma constitucional acaba sempre por ser utilizada. O que importa não é estabelecer se a um caso concreto se dê aplicação direta ou indireta, mas sim, confirmar a eficácia, com ou sem uma específica normativa ordinária, da norma constitucional frente às relações pessoais e socioeconômicas. $^{33}$

A introdução das cláusulas gerais pelos juristas que elaboraram o Código Civil de 2002 serviu para revigorá-lo, ou seja, conduziu o Código à constatação do movimento pendular em que oscilam a necessidade da certeza jurídica (raíz romanogermânica), e, de outro lado, a busca de soluções afinadas à mutabilidade do tempo e das circunstâncias. ${ }^{3435}$

\footnotetext{
${ }^{31}$ PERLINGIERI, Pietro. Perfis,.op.cit., p. 09-11.

${ }^{32}$ PERLINGIERI, Pietro. Perfis,.op.cit., p. 09-11.

${ }^{33}$ PERLINGIERI, Pietro. Perfis,op.cit., p. 10-12.

${ }^{34}$ COSTA, Judith Martins. As Cláusulas Gerais como Fatores de Mobilidade do Sistema Jurídico, Revista dos Tribunais, ano 81, junho/92, v. 680, RT 680, p. 54.

${ }^{35}$ COSTA, Judith Martins. As Claúsulas Gerais, op.cit., p. 50-51. Ensina ainda a professora neste mesmo texto e página que a grande diferença entre princípio e cláusula geral, do ponto de vista da atividade judicial, está, pois, em que estas permitem a formação da norma não através da interpretação dos
} 


\section{REVI STA ELETRÔNI CA DA FACULDADE DE DIREITO DE FRANCA \\ www.revista.direitofranca.br \\ v. 7, n.1, jul/ 2013, I SSN: 1983-4225}

Constatamos, assim, que no Código Civil de 2002 há algumas cláusulas gerais previstas expressamente, como a da função social do contrato (art. 421), probidade e boa-fé (art. 422), enriquecimento sem causa (art. 884), ato ilícito (art. 186 e 927), abuso de direito (art. 187), dentre outros como a própria função social da propriedade (art. 1.228), permitindo assim ao juiz a ampliação da margem interpretativa ${ }^{36}$, e, por conseqüência, do poder de julgar o caso concreto.

E no que interferem esses princípios nas obrigações entre as partes? Como poderá ser encontrado apoio nesses princípios e no ordenamento em geral para se dirimirem os conflitos entre os moradores de loteamento fechado que não querem participar do rateio, e as associações que querem fazer as cobranças? Pelo princípio da eticidade o intérprete diante das palavras equidade, probidade e boa-fé poderá dar conteúdo ético à norma, não fazendo da norma modelo rígido e, sim, aberto, em que se possa a todo instante recorrer aos princípios morais, sociais, históricos e culturais que governam a vida social. Pelo princípio da socialidade as regras jurídicas colocadas no Código, inclusive aquelas do direito das obrigações, devem estar num plano de vivência social, como é o caso dos contratos que podem ser gerados pelo poder negocial das partes, ou seja, o poder de dar origem às suas cláusulas contratuais, daí ter sido estabelecido artigo do Código que o contrato deve ser analisado em razão da sua função social. ${ }^{37}$ Pelo princípio da operabilidade, toda vez que tiver de ser analisada uma norma jurídica devemos ver sua realizabilidade, o Direito é feito para ser executado, realizado,

princípios, mas pela criação da síntese judicial onde encontram como elemento de atuação fatos ou valores éticos, sociológicos, históricos, psicológicos.

${ }^{36}$ Interpretar significa descobrir o sentido e o alcance da norma, procurando a significação dos conceitos jurídicos tudo em razão daqueles motivos mencionados da vaguidade, imperfeição dos textos, má redação da lei terá o magistrado que interpretar a norma para aplicá-la ao caso sub judice. Isto tudo se deve pelo fato de que o sentido da norma se adapta a mudanças que se operam na vida social, sendo que o ato de interpretar terá como funções: a) conferir a aplicabilidade da norma jurídica às relações sociais que lhe deram origem; b) estender o sentido da norma a relações novas, inéditas ao tempo de sua criação; e c) conferir ao preceito normativo correspondência às necessidades reais e atuais de caráter social. Ao se interpretar a norma, deve-se ter atenção aos fins sociais e aos valores que pretende atingir, daí atentarmos às novas situações de fato como é o caso do condomínio atípico ou de fato que atenda a valores que objetivam aquele grupo social, qual seja, segurança, manutenção e conservação de seu patrimônio. In DINIZ, Maria Helena. Compêndiode introdução à ciência do Direito. São Paulo:Saraiva, 14 ${ }^{\mathrm{a}}$ edição, 2001, p. 415.

${ }^{37}$ Miguel Reale, ensina ainda que no Projeto do Novo Código deu-se preferência a modelos jurídicos abertos, conferindo-se ao juiz o poder-dever de julgar, com base nos princípios éticos da equidade, da boa-fé como pressupostos da conduta geral na sociedade civil. InO Projeto de Código Civil, op.cit., São Paulo:Saraiva, 1986, p.9. 


\section{REVI STA ELETRÔNI CA DA FACULDADE DE DIREITO DE FRANCA \\ www.revista.direitofranca.br \\ v. 7, n.1, jul/ 2013, I SSN: 1983-4225}

operado $^{38}$, ou seja, o próprio sistema jurídico existente permite a integração do que está às margens do Código, disperso em leis extravagantes ou "microssistemas", e que poderá ser feito através das cláusulas gerais.

\section{CONCLUSÃO}

Poe todas as considerações acima suscitadas ganham relevância para conferir guarida à obrigação de participar do rateio das despesas comuns em loteamentos fechados pelos proprietários de lotes, além da aceitação tácita, há ainda o princípio da solidariedade estampado no artigo $3^{\circ}$, inciso I da Constituição Federal, que agrega-se como um valor dotado de exigibilidade pois decorre do princípio superior da Constituição Federal, qual seja, o da dignidade da pessoa humana.

A solidariedade está vinculada às cláusulas gerais, uma vez que estas buscam o comportamento solidário entre as partes compatível com a concepção social, seja no contrato (art. $421 \mathrm{CC}$ ) ou mesmo na propriedade (art. 1.228, § $1^{\circ}$ do CC). ${ }^{39}$

Assim sendo, com base nesse princípio da solidariedade bem como nos da justiça e bem-estar social ${ }^{40}$, pode-se igualmente pretender que os proprietários de lotes em loteamento fechado contribuam para sua manutenção e conservação.

E, a influência da função social passou a alcançar não só os fatos regulados pelo Direito, mas também aqueles para o qual o sistema é inoperante, como são as hipóteses de situações de fato, que surgem de relações interpessoais, à margem do ordenamento, porém dentro de um universo em que o Estado exerce papel garantidor do bem-estar social, incluindo, nesses casos, solução para o problema das despesas comuns dentro dos loteamentos fechados. ${ }^{41}$

\footnotetext{
${ }^{38}$ REALE, Miguel. O Projeto de Código,São Paulo:Saraiva, 1986, p. 07-13.

${ }^{39}$ DONNINI, Rogério Ferraz. Responsabilidade, op.cit., p. 117.

40 Bem-estar e desenvolvimento podem ser entendidos como valores mutuamente complementares. O bem-estar deve ser encarado como valor objetivo, conferindo oportunidades iguais a todos, o objetivo do artigo 3, inciso III da CF/88 é garantir o desenvolvimento nacional, equalizando as oportunidades de participação econômica e social, daí ser o bem-estar um valor social. In FERRAZ JUNIOR, Tercio Sampaio; DINIZ, Maria Helena; GEORGAKILAS, Ritinha Stevenson. Constituição de 1988 Legitimidade - vigência e eficácia, São Paulo:Atlas, p. 30-31.

${ }^{41}$ SOARES, Danielle Machado. Condominio de fato,op.cit., p. 34.
} 


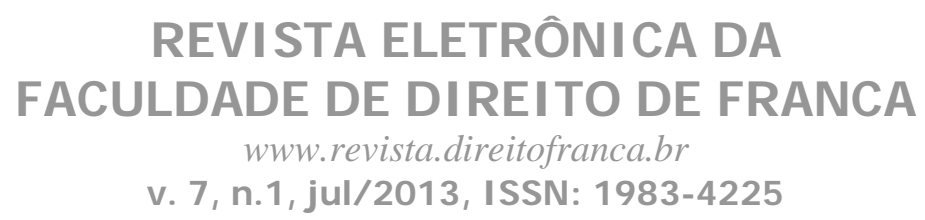

\section{REFERÊNCIAS BIBLIOGRÁFICAS}

ALLENDE, Guillermo L. Panorama de derechos reales. Buenos Aires:La Ley, 1967.

ALVES, José Carlos Moreira. Posse - estudo dogmático. 2a edição, Rio de Janeiro: Forense, 1991.

ALVES, Francisco de Assis. Associações, sociedades e fundações no Código Civil de 2002: perfil e adaptações. São Paulo: Juarez de Oliveira, 2004.

ARAGÃO, Severiano Ignácio de. Regime jurídico do condomínio fechado. Rio de Janeiro:Forense, 2001.

ARRUDA ALVIM NETO, José Manoel de. Breves Anotações para uma Teoria Geral dos Direitos Reais, Posse e Propriedade, Doutrina e Jurisprudência, organização de Yussef Said Cahali, São Paulo:Saraiva, 1987.

- Confronto entre uma situação de direito real e

outra de direito obrigacional, parecer sem publicação, maio/98.

ASCENÇÃO, José Oliveira. Direito Civil: Direitos Reais. Coimbra:Coimbra Editora, 1993.

AZEVEDO, Álvaro Villaça. Curso de Direito Civil. Obrigações, $3^{\text {a }}$ edição, São Paulo:RT, 1981.

AZEVEDO, Antonio Junqueira de. Restrições convencionais de loteamento. Obrigações proter rem e suas condições de persistência. Base do negócio jurídico. Revista dos Tribunais, $n^{0}$ 741/115, Ano 86, julho/97.

AZEVEDO, Eurico de Andrade. Loteamento especial ou loteamento fechado em condomínio. Revista de Direito Imobiliário, nº 11.

AZEVEDO, Marcelo Sampaio Soares de. O loteamento fechado na legislação municipal. Dissertação de Mestrado, PUC/SP, 2002.

BARASSI, Lodovico. Il diritto di proprietà e la funzione social. Roma, 1939.

BARROSO, Roberto. O Município e o parcelamento do solo urbano. Revista de Direito Administrativo, Rio de Janeiro, 194:54-62, out/dez, 1993.

BATALHA, Wilson de Souza Campos. Loteamentos e condomínios. São Paulo:Max Limonad, 1953

BETTI, Emilio. Interpretazione della legge e degli atti giuridici. Milano:Dott A. Giuffrè Editore, 1971. 


\section{REVI STA ELETRÔNI CA DA FACULDADE DE DIREITO DE FRANCA \\ www.revista.direitofranca.br \\ v. 7, n.1, jul/ 2013, I SSN: 1983-4225}

CAMBLER, Everaldo Augusto. Incorporação imobiliária - ensaio de uma teoria geral. São Paulo: Revista dos Tribunais, 1993.

CASTRO, Flávia de Almeida Viveiros de. Obrigações propter rem e condomínios atípicos. Revista dos Tribunais, $n^{\circ}$ 799/64, 91º Ano, maio/2002.

CORDEIRO, Antonio Menezes. A posse: perspectivas dogmáticas actuais. 2a edição, Coimbra: Livraria Almedina, 1999.

COSTA, Judith Martins. O direito privado como um "sistema em construção" - as cláusulas gerais no projeto do Código Civil brasileiro.Revista dos Tribunais, n 753/24, Ano 87, Julho/98.

As cláusulas gerais como fatores de mobilidade do sistema jurídico. Revista dos Tribunais, $\mathrm{n}^{\circ}$ 680, Ano 81, Junho/92.

COSTA, Mário Júlio de Almeida. Direito das obrigações. $7^{\mathrm{a}}$ edição, Coimbra: Almedina, 1999.

DINIZ, Maria Helena. As lacunas no Direito. São Paulo:Saraiva, 2002.

- Compêndio de introdução à ciência do Direito. São Paulo:Saraiva, 14ª edição, 2001.

DONNINI, Rogério Ferraz. Responsabilidade pós-contratual. São Paulo:Saraiva, 2004.

ERPEN, Décio Antonio; PAIVA, João Pedro Lamana; MEZZARI, Mario Pazutti. Condomínio horizontal de lotes - edificação de livre escolha do condômino. Revista Jurídica 310, agosto, 2003.

FACHIN, Luiz Edson. A cidade nuclear e o direito periférico: reflexões sobre a propriedade urbana. Revistas dos Tribunais, $n^{\circ}$ 743/108.

A função social da posse e a propriedade contemporânea (uma perspectiva de usucapião imobiliário rural). Porto Alegre: Sergio Antonio Fabris, 1988.

A desapropriação como instrumento de reforma. In Arquivos do Ministério da Justiça, Brasília: Fundação Petrônio Portela, Ano 39, n 166, out/85.

FAZANO, Haroldo Guilherme Vieira. Da propriedade horizontal e vertical. Dissertação de Mestrado, PUC/SP, 2001.

FERNANDES, Edésio. Solo Urbano: novas diretrizes para o parcelamento - Lei 9.785/99. Revista Jurídica, Sapucaia do Sul, v. 47, n 261, jul/1999. 


\section{REVI STA ELETRÔNI CA DA FACULDADE DE DIREITO DE FRANCA \\ www.revista.direitofranca.br \\ v. 7, n.1, jul/ 2013, I SSN: 1983-4225}

FERRAZ JUNIOR, Tércio Sampaio; DINIZ, Maria Helena; GEORGAKILAS, Ritinha Stevenson. Constituição Federal de 1988 - legitimidade - vigência e eficácia supremacia. São Paulo:Atlas, 1988.

FREITAS, José Carlos. Da legalidade dos loteamentos fechados. Revista dos Tribunais, $n^{\circ}$ 750/148, 87 Ano, abril, 1998.

GASPARINI, Diógenes. Loteamento em condomínio. Revista de Direito Público, $\mathrm{n}^{0}$ 68/316-319, 1983.

GATTI, Edmundo. Teoria generale dos derechos reales. Buenos Aires: Abelado Perrot, 1967.

GRAU, Eros Roberto. Condomínio horizontal edificado. Revista de Direito Público, $\mathrm{n}^{\circ}$ 79/198, 1986

GRINOVER, Ada Pelegrini. A tutela jurisdicional dos interesses difusos. Revista de Processo. N 14.

JOSSERAND, Louis. Derecho Civil. Tradução Santiago Cunchillos y Monterda Buenos Aires. Edciones Juridicas Europa America, Tomo 1, Vol. III, 1950.

KOJRANSKI, Nelson. Direitos Reais in Domingos Fraciulli Neto e Ives Gandra da Silva Martins (coord). O Novo Código Civil. São Paulo: LTR, 2003.

Loteamento fechado. Revista do Instituto dos Advogados de São

Paulo, São Paulo, nº especial, 1997.

Loteamento fechado: o problema das despesas comuns. Revista do Instituto dos Advogados de São Paulo. São Paulo, v. 02, n 3, jan/jun, 1999.

Loteamento e condomínio fechados. Jornal Tribuna do Direito, jan, 1999.

LIMA, Getúlio Targino de. Apontamentos a respeito do direito de propriedade, in Direito Civil Constitucional, Renan Lotufo (coord.), São Paulo:Malheiros Editora, Caderno 3, 2002.

LOPES, João Batista. Condomínio. São Paulo: Revista dos Tribunais, 6ª edição, 1997.

LOUREIRO, Francisco Eduardo. A propriedade como relação jurídica complexa. Rio de Janeiro: Renovar, 2003.

MALUF, Carlos Alberto Dabus. Limitações ao direito de propriedade. São Paulo: Saraiva, 1997. 


\section{REVI STA ELETRÔNI CA DA \\ FACULDADE DE DIREITO DE FRANCA}

www.revista.direitofranca.br

v. 7, n.1, jul/ 2013, I SSN: 1983-4225

. O Condomínio edilício no novo Código Civil. São

Paulo:Saraiva, 2004.

MEIRELLES, Hely Lopes.Direito administrativo brasileiro. São Paulo:Malheiros, 1992.

As restrições de loteamento e as leis urbanísticas supervenientes. Revista de Direito Administrativo, $\mathrm{n}^{0}$ 120, Rio de Janeiro, 120: 479488, abril/junho, 1975.

MUKAI, Toshio; ALVES, Alaor Caffé; LOMAR, Paulo José Villela. Loteamento e desmembramentos urbanos. São Paulo: Sugestões Literárias, 1980.

NANNI, Giovanni Ettore. Enriquecimento sem causa. São Paulo:Saraiva, 2004.

PERLINGIERI, Pietro. Perfis do direito civil - introdução ao direito civil constitucional. Tradução Maria Cristina De Cicco, $2^{\circ}$ edição, Rio de Janeiro:Renovar, 2002.

REALE, Miguel. O projeto de Código Civil, situação atual e seus problemas fundamentais. São Paulo:Saraiva, 1986.

O projeto do novo Código Civil após sua aprovação pelo Senado Federal. São Paulo:Saraiva, 2001.

RIZZARDO, Arnaldo. Promessa de compra e venda e parcelamento do solo urbano: Lei $n^{\circ}$ 6.766/79 e 9.785/99. 6ª edição, São Paulo:RT, 2003.

ROPPO, Enzo. O contrato. Coimbra: Almedina, 1998.

RUGGIERO, Biasi. Condomínio fechado: loteamento burlado. Revista do Advogado, São Paulo, n 18, jul/1985.

SOARES, Danielle Machado. Condomínio de fato. Rio de Janeiro:Renovar, 1999.

TEPEDINO, Gustavo. Temas de Direito Civil. Rio de Janeiro: Renovar, 1999.

.(coord.) Problemas de Direito Civil. Rio de Janeiro: Renovar, 1999

.Aspectos da propriedade privada na ordem constitucional. In

Estudos Jurídicos. Rio de Janeiro, 1991

VIANA, Marco Aurélio. Loteamento fechado e loteamento horizontal. Rio de Janeiro: Aide, 1991. 


\section{REVI STA ELETRÔNI CA DA FACULDADE DE DIREITO DE FRANCA}

www.revista.direitofranca.br

v. 7, n.1, jul/ 2013, I SSN: 1983-4225

VIANA, Rui Geraldo Camargo e Rosa Maria de Andrade Nery (coordenadores). Temas Atuais de Direito Civil na Constituição Federal. São Paulo: RT, 2000.

Mestrado, USP, 1983.

O Parcelamento do solo urbano. Dissertação de 